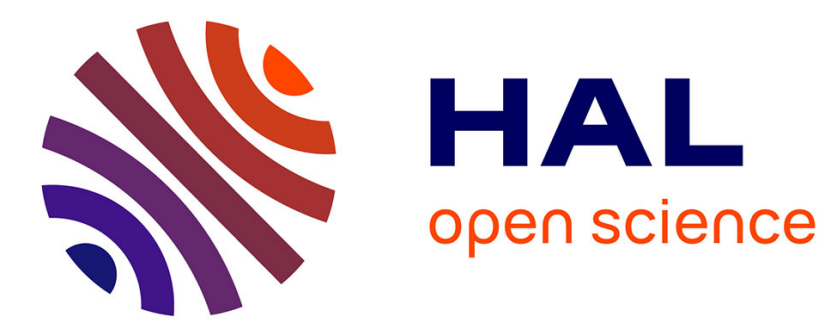

\title{
Network Patterns of Legislative Collaboration in Twenty Parliaments
}

François Briatte

\section{To cite this version:}

François Briatte. Network Patterns of Legislative Collaboration in Twenty Parliaments. Network Science, 2016, 4 (2), pp.266-271. 10.1017/nws.2015.31 . halshs-01363580

\section{HAL Id: halshs-01363580 \\ https://shs.hal.science/halshs-01363580}

Submitted on 19 Apr 2017

HAL is a multi-disciplinary open access archive for the deposit and dissemination of scientific research documents, whether they are published or not. The documents may come from teaching and research institutions in France or abroad, or from public or private research centers.
L'archive ouverte pluridisciplinaire $\mathbf{H A L}$, est destinée au dépôt et à la diffusion de documents scientifiques de niveau recherche, publiés ou non, émanant des établissements d'enseignement et de recherche français ou étrangers, des laboratoires publics ou privés.

\section{다(1) (2)}

Distributed under a Creative Commons Attribution - ShareAlikel 4.0 International 


\title{
Network Patterns of Legislative Collaboration in Twenty Parliaments
}

\author{
François Briatte \\ francois.briatte@sciencespo.fr
}

Short presentation note

\begin{abstract}
In recent years, the ties that Members of Parliament (MPs) create by cosponsoring legislation together have attracted interest from scholars adopting a network approach to lawmaking. This brief note expands the empirical base of these studies by introducing a dataset of 150 bill cosponsorship networks that cover 27 parliamentary chambers from 19 European countries, plus Israel. The data show the extent of partisanship expressed by MPs through their propensity to cosponsor bills within and across party lines, in several different parliamentary systems.
\end{abstract}

In recent years, the ties that Members of Parliament (MPs) create by cosponsoring legislation together have attracted interest from scholars adopting a network approach to lawmaking. The general objective of that approach, which takes advantage of important developments in the statistical modeling of political and social networks (Cranmer \& Desmarais 2011, Snijders 2011), consists in identifying the relational determinants that underlie legislative production, such as shared attributes of legislators or 'friend-of-a-friend' effects. From that perspective, the formation of cosponsorship ties is a possible entry point into the collaborative structure of parliamentary chambers (Kirkland, 2014), and a useful complement to legislative productivity and roll-call voting records in the study of parliamentary behaviour.

To our knowledge, such network approaches to legislative cosponsorship have so far been conducted on a limited range of country cases. The literature that we reviewed includes numerous studies of both Congressional houses of the United States, pioneered by the work of Fowler (2006a: 2006b), as well as studies of its state legislatures (Bratton \& Rouse 2011. Clark \& Caro, 2013; Kirkland, 2013). We also located studies of legislative cosponsorship networks in the parliaments of Argentina (Alemán \& Calvo 2013: Micozzi 2014), Chile (Alemán \& Calvo, 2013) and a subset of the Romanian parliament (Chiru \& Neamţu 2012) 1 However, no comprehensive dataset currently exists to allow for the comparative analysis of such networks over a more diverse set of legislative environments.

This brief note therefore aims at contributing to network studies of legislative cosponsorship by expanding their empirical base to several additional countries. Through the use of various web scraping technologies (Munzert et al. 2015), we tried to collect information on private bills ${ }^{2}$ and their sponsors from the official websites of 33 parliaments, or from

${ }^{1}$ Our search also returned visual explorations of bill cosponsorship in the lower houses of the French Coulmont 2011) and Czech (Gregor 2013) parliaments, and similar research on Korean legislators (Ji-yeon Lee \& Yoon 2014).

${ }^{2}$ We focused our attention on private bills, defined as laws initiated by one or more MPs that become binding if they make it through the legislative process of their country of introduction. This definition is compatible with theoretical assumptions on how MPs signal their positions to their constituents or to third parties, and is comparable across countries. 
Table 1: Overview of country-chamber sample

\begin{tabular}{llllcc}
\hline \hline Region & Country & Chamber & Period & Years & Legislatures \\
\hline East & Bulgaria & Unicameral & $2005-2015$ & 11 & 4 \\
& Czech Republic & Lower & $1996-2015$ & 20 & 6 \\
& & Upper & $1996-2015$ & 20 & 6 \\
& Estonia & Unicameral & $2007-2015$ & 9 & 3 \\
& Hungary & Unicameral & $1998-2015$ & 18 & 5 \\
& Lithuania & Unicameral & $1992-2015$ & 24 & 6 \\
& Romania & Lower & $1996-2015$ & 20 & 5 \\
& & Upper & $1996-2015$ & 20 & 5 \\
& Slovakia & Unicameral & $1998-2015$ & 18 & 5 \\
West & Austria & Lower chamber only & $1994-2015$ & 22 & 7 \\
& Belgium & Lower & $1991-2015$ & 25 & 7 \\
& & Upper & $1995-2014$ & 20 & 5 \\
& France & Lower & $1986-2015$ & 259 & 6 \\
& & Upper & $1986-2015$ & 30 & 7 \\
& Ireland & Lower & $1997-2015$ & 19 & 4 \\
& & Upper & $1997-2015$ & 19 & 4 \\
& Italy & Lower & $1983-2015$ & 33 & 9 \\
& & Upper & $1996-2015$ & 20 & 5 \\
& Portugal & Unicameral & $1991-2015$ & 25 & 7 \\
& Switzerland & Lower & $1995-2015$ & 21 & 5 \\
& & Upper & $1995-2015$ & 21 & 5 \\
Asia & Israel & Unicameral & $2001-2015$ & 15 & 5 \\
& Denmark & Unicameral & $2009-2015$ & 7 & 3 \\
& Finland & Unicameral & $1999-2014$ & 16 & 4 \\
& Iceland & Unicameral & $1995-2015$ & 21 & 6 \\
& Norway & Unicameral & $1985-2015$ & 31 & 8 \\
& Sweden & Unicameral & $1988-2015$ & 28 & 8 \\
& & & & & \\
& & & & & 7 \\
6
\end{tabular}

${ }^{a}$ Missing legislature 10 (1993-1997) of the French lower chamber.

related open data portals. Our country sample included all current member states of the European Union, plus the four members of the European Free Trade Association (Iceland, Liechtenstein, Norway and Switzerland) and Israel.

Table 1 summarises the data that we managed to collect, which cover 20 countries and 27 parliamentary chambers, over a total of 558 years and 150 legislatures, understood as periods between two nationwide legislative elections. The sample contains a mix of unicameral and bicameral parliamentary systems from Eastern, Northern and Western Europe, including three federal regimes (Austria, Belgium and Switzerland). The R code (R Core Team 2015) used to collect the data and assemble the cosponsorship networks is available at https://github.com/briatte/parlnet, along with detailed replication instructions.

Using the same parliamentary sources as for bills, we then retrieved as much information as possible on the individual legislators who nominally sponsored the bills. The variables collected across all countries include sponsor age, sex and parliamentary career information (time in office, constituency, committee membership and party affiliation), for a total of over 18,000 MPs who appeared on at least one cosponsored bill. To further characterize the positions of bill sponsors relative to each other, we also proceeded to match their party 


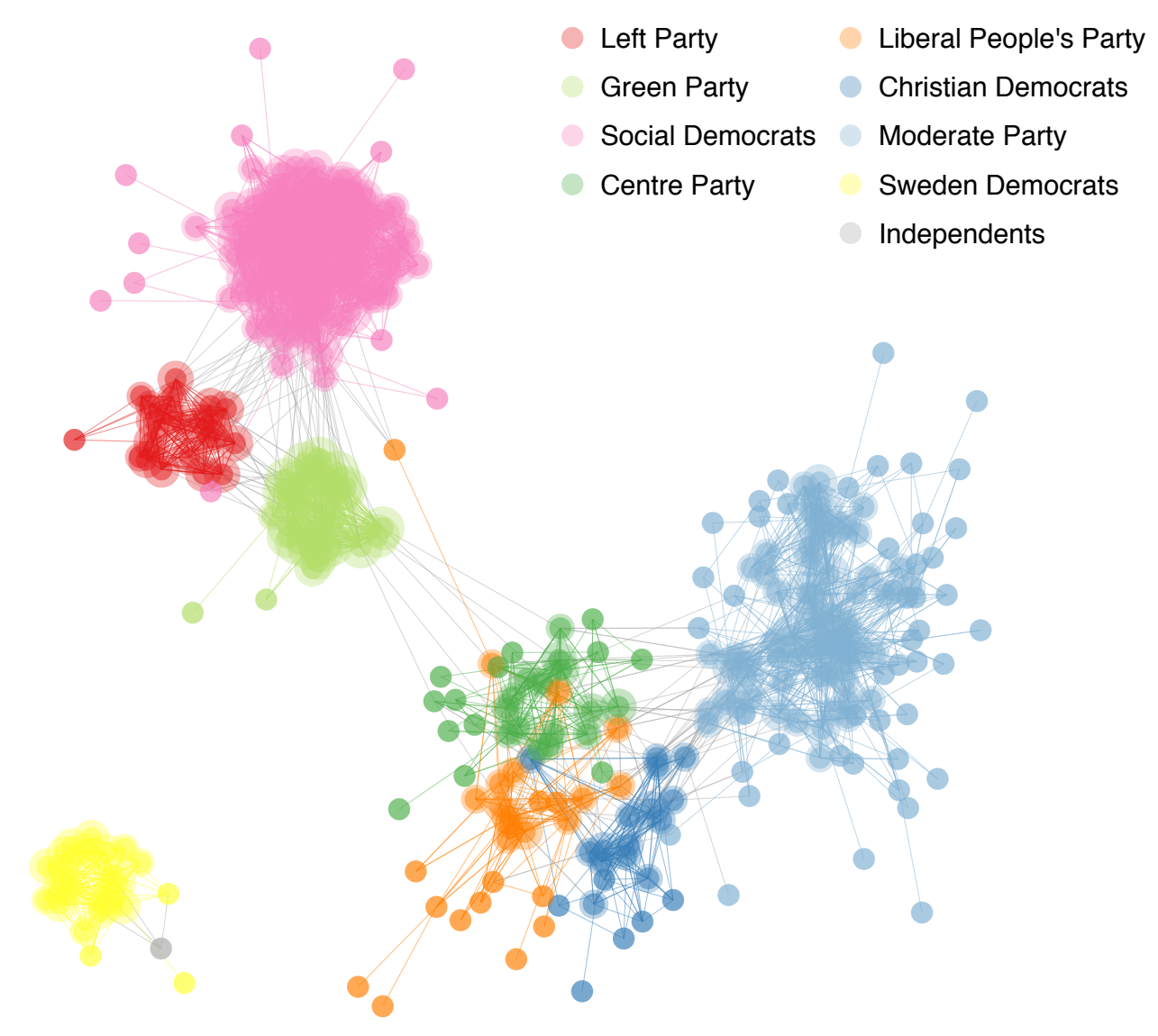

Figure 1: Bill cosponsorships in the Swedish Riksdag, years 2010-2014. Vertex colors designate party affiliations.

affiliations with an indication of where the party sits on a standardized Left/Right scale. In order to do so, we used the scores available in the latest edition of the ParlGov database (Döring \& Manow 2014), which are time-invariant scores computed as the weighted mean values of party positions taken from several expert surveys on political parties. ${ }^{3}$

Figure 1 shows one of the cosponsorship networks that can be constructed from the data we collected, using force-directed placement (Fruchterman \& Reingold 1991). The network, which shows bill cosponsorship ties in the ongoing legislature of the unicameral parliament of Sweden, is a one-mode projection of the $b \times a$ two-mode matrix, where $b$ denotes bills and $a$ denotes their sponsors, that connects the first author of each bill to all other sponsors on that bill. The resulting adjacency matrix $A_{i j}$ of directed ties between MPs $(i, j)$ is asymmetric and contains no self-loops.

In order to further explore the collaborations that take place in legislative cosponsorship networks, we also built interactive versions of the same graphs, which allow the user to explore the ego networks of specific MPs. These visualisations, an example of which is shown in Figure 2 are available online at http://f.briatte.org/parlviz/

\footnotetext{
${ }^{3}$ See http://www.parlgov.org/documentation/party-positions/for further details on ParlGov Left/Right party positions. The scores, which range from 0 to 10 , are listed in full in the appendix, along with the recodings that we applied to match the ParlGov data with ours.
} 


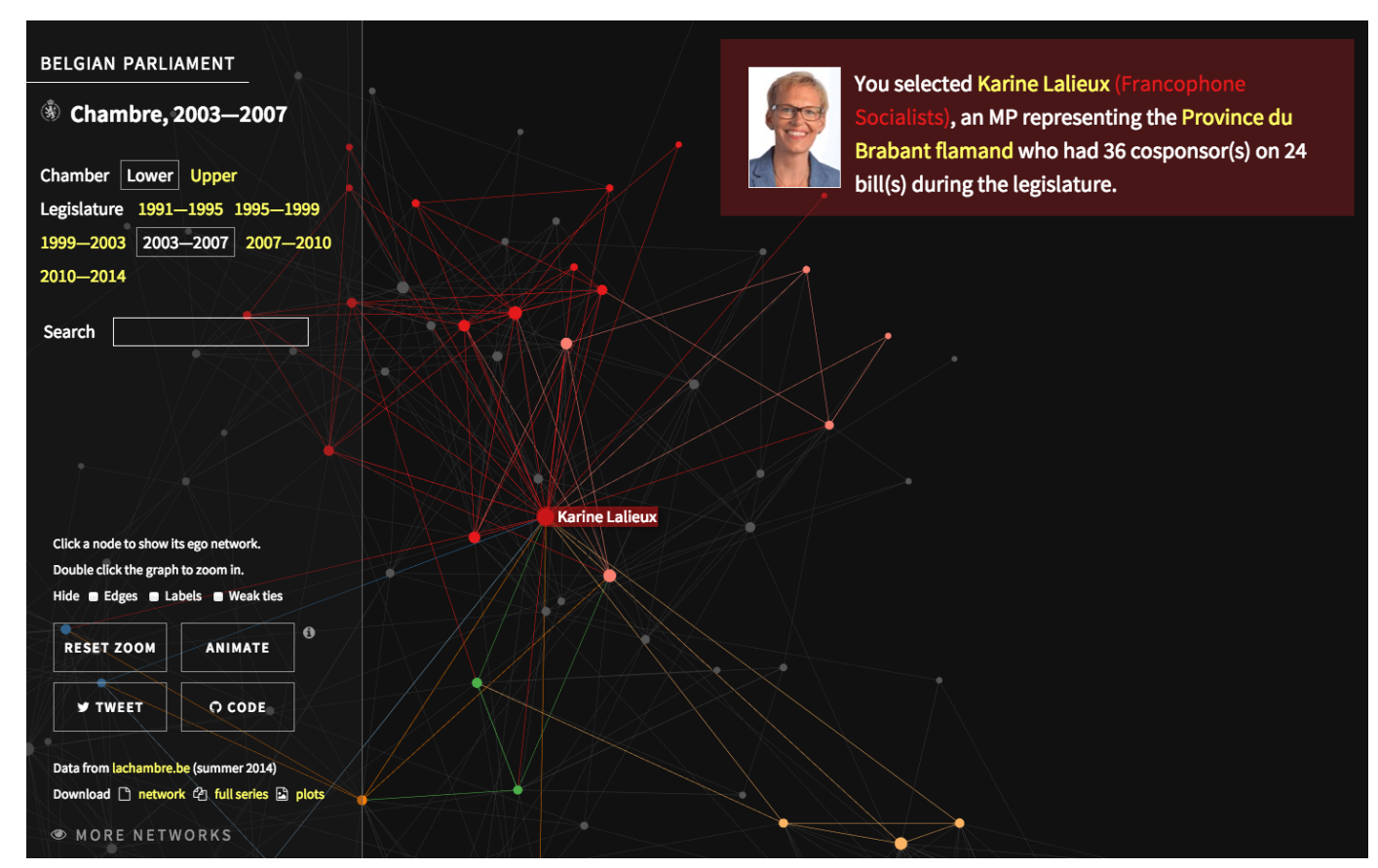

Figure 2: Visualization of the Belgian Chamber of Deputies, years 2003-2007.

Last, because legislative cosponsorship networks are based on ties that represent one or more than shared bill(s) between two MPs, we computed several measures to weight their edges accordingly. These measures (raw cosponsorship counts, the weighted quantity of bills cosponsored and the weighted propensity to cosponsor) are taken from existing studies of legislative cosponsorship in the U.S. Congress (Fowler. 2006a Gross et al. 2012), and are documented in full in the appendix to this note.

As illustrated in Figure 1 and as visible in the interactive visualizations previously mentioned, all of the 146 observed networks clearly show the influence of party affiliations over decisions to cosponsor bills. Using these data, the extent of partisanship expressed by MPs through their propensity to cosponsor bills within and across party lines might be measured through different methods: several studies of the U.S. Congress (Zhang et al. 2008; Waugh et al. 2009. Moody \& Mucha 2013) use the modularity network statistic (Newman \& Girvan 2004: Leicht \& Newman, 2008) to that effect, but the data are also amenable to other estimation methods, such as exponential random graph models (Cranmer \& Desmarais 2011, Snijders 2011). Such measures should confirm that, as Sartori (1976/2005) observed several decades ago, the distribution of power between political parties can take many different forms in highly competitive electoral environments, as "the fragmentation of the party system can reflect either a situation of segmentation or a situation of polarisation, i.e., of ideological distance" (p. 111).

The levels of party polarization shown in the networks under study represent only one of many possible ways to explore the individual and institutional determinants that govern over the decisions of MPs to cosponsor each other's bills. In similar fashion to Moody and Mucha (2013), we therefore hope that the data presented in this note, might serve as an introduction to a complex empirical puzzle, extended to a set of country cases that allow for comparative inquiry, and supported by interactive network visualizations. 


\section{REFERENCES}

Alemán, Eduardo. (2015). Coauthorship ties in the Colombian congress, 2002-2006. Colombia Internacional, (83), 23-42.

Alemán, Eduardo, \& Calvo, Ernesto. (2013). Explaining policy ties in presidential congresses: A network analysis of bill initiation data. Political Studies, 61(2), 356-377.

Bratton, Kathleen A., \& Rouse, Stella M. (2011). Networks in the legislative arena: How group dynamics affect cosponsorship. Legislative Studies Quarterly, 36(3), 423-460.

Chiru, Mihail, \& Neamţu, Silvia. 2012 (jun). Parliamentary representation under changing electoral rules: Cosponsorship in the Romanian parliament. Inaugural General Conference of the ECPR Standing Group on Parliaments: 'Parliaments in Changing Times'.

Clark, Jennifer Hayes, \& Caro, Veronica. (2013). Multimember districts and the substantive representation of women: An analysis of legislative cosponsorship networks. Politics \& Gender, 9(1), 1-30.

Coulmont, Baptiste. 2011 (sep). Travail de députés. Blog post at http://coulmont.com/blog/2011/09/02/travail-de-deputes/.

Cranmer, Skyler J., \& Desmarais, Bruce A. (2011). Inferential network analysis with exponential random graph models. Political Analysis, 19(1), 66-86.

Döring, Holger, \& Manow, Philip. 2014 (12). Parliaments and governments database (ParlGov): Information on parties, elections and cabinets in modern democracies. Stable version 14-12.

Fowler, James H. (2006a). Connecting the Congress: A study of cosponsorship networks. Political Analysis, 14(4), 456-487.

Fowler, James H. (2006b). Legislative cosponsorship networks in the U.S. House and Senate. Social Networks, 28(4), 454-465.

Fruchterman, Thomas M.J., \& Reingold, Edward M. (1991). Graph drawing by forcedirected placement. Software: Practice and Experience, 21(11), 1129-1164.

Gregor, Kamil. 2013 (aug). Visualizing politics: Network analysis of bill sponsors. Blog post at http://blog.openingparliament.org/post/59496651147/visualizing-politicsnetwork-analysis-of-bill.

Gross, Justin H., Kirkland, Justin H., \& Shalizi, Cosma. 2012 (5). Cosponsorship in the U.S. Senate: A multilevel two-mode approach to detecting subtle social predictors of legislative support. Unpublished manuscript.

Ji-yeon Lee, Hyun-joo Jo, \& Yoon, Ji Won. (2014). Network analysis of Korean legislators using bipartite network projection. Journal of Internet Computing and Services, 15(4), 103-110.

Kirkland, Justin H. (2013). Hypothesis testing for group structure in legislative networks. State Politics \& Policy Quarterly, 13(2), 225-243.

Kirkland, Justin H. (2014). Chamber size effects on the collaborative structure of legislatures. Legislative Studies Quarterly, 39(2), 169-198. 
Leicht, Elizabeth A., \& Newman, Mark E. J. (2008). Community structure in directed networks. Physical Review Letters, 100(11), 118703.

Micozzi, Juan Pablo. (2014). Alliance for progress? multilevel ambition and patterns of cosponsorship in the Argentine House. Comparative Political Studies, 47(8), 1186-1208.

Moody, James, \& Mucha, Peter J. (2013). Portrait of political party polarization. Network Science, 1(1), 119-121.

Munzert, Simon, Rubba, Christian, Meißner, Peter, \& Nyhuis, Dominic. (2015). Automated data collection with $R$ : A practical guide to web scraping and text mining. New York: Wiley.

Newman, Mark E.J., \& Girvan, Michelle. (2004). Finding and evaluating community structure in networks. Physical Review E, 69(2), 026113.

$\mathrm{R}$ Core Team. (2015). $R$ : A language and environment for statistical computing. R Foundation for Statistical Computing, Vienna, Austria.

Sartori, Giovanni. (1976/2005). Parties and party systems: A framework for analysis. Colchester: ECPR Press.

Snijders, Tom A.B. (2011). Statistical models for social networks. Annual Review of Sociology, 37, 131-153.

Waugh, Andrew Scott, Pei, Liuyi, Fowler, James H., Mucha, Peter J., \& Porter, Mason A. 2009 (jul). Party polarization in Congress: A network science approach. Working paper at http://ssrn.com/abstract=1437055.

Zhang, Yan, Friend, A.J., Traud, Amanda L., Porter, Mason A., Fowler, James H., \& Mucha, Peter J. (2008). Community structure in Congressional cosponsorship networks. Physica A: Statistical Mechanics and its Applications, 387(7), 1705-1712. 